\title{
A novel method for production of peroxidase enzyme from garden radish root source using a spouted bed reactor modeling and optimization approach
}

Shahrbanoo Hamedi

Shahid Bahonar University of Kerman

M. Mehdi Afsahi ( $\nabla$ nec.rayan@gmail.com)

Shahid Bahonar University of Kerman

Ali Riahi-Madvar

Kosar University of Bojnord

\section{Research Article}

Keywords: Drying, Response surface methodology, Spouted bed dryer, Garden radish, Peroxidase enzyme

Posted Date: February 16th, 2021

DOI: https://doi.org/10.21203/rs.3.rs-198843/v1

License: (1) (1) This work is licensed under a Creative Commons Attribution 4.0 International License.

Read Full License

Version of Record: A version of this preprint was published at Scientific Reports on July 13th, 2021. See the published version at https://doi.org/10.1038/s41598-021-93563-4. 


\section{Abstract}

The main advantages of the dried enzymes are the lower cost of storage and longer time of preservation for industrial applications. In this study for the first time, the spouted bed reactors were utilized for drying the garden radish (Raphanus sativus L.) root extract as a cost-effective source of the peroxidase enzyme. The response surface methodology (RSM) was used to evaluate the individual and interactive effects of main parameters (the inlet air temperature $(T)$ and the air flow rate $(Q)$ ) on the residual enzyme activity (REA). The maximum REA of $38.7 \%$ was obtained at the $T=50{ }^{\circ} \mathrm{C}$ and $\mathrm{Q}=1.4$. In order to investigate the drying effect on the catalytic activity, the optimum reaction conditions ( $\mathrm{pH}$ and temperature), as well as kinetic parameters, were investigated for the fresh and dried enzyme extracts (FEE and DEE). The obtained results showed that optimum $\mathrm{pH}$ was decreased about $12.3 \%$ while $85.7 \%$ increase was observed in optimum temperature of DEE compare to FEE. Moreover, kinetic parameters, thermal-stability, and shelf life of the enzyme were considerably improved after drying by the spouted bed. Overall, the results confirmed that a spouted bed reactor can be used as a promising method for drying heat-sensitive materials such as peroxidase enzyme.

\section{Introduction}

Enzymes are protein catalysts and in the form of liquid, are denaturized by heat and decomposed through proteolytic degradation ${ }^{1}$. In this regard, various methods including the use of osmolytes ${ }^{2}$, mutagenesis ${ }^{3}$, immobilization ${ }^{4-6}$, and drying ${ }^{7}$ have been developed to increase the thermal as well as the storage stability of enzymes. One of the impressive and applicable methods for improving the enzyme stability is enzyme drying. This technique significantly reduces the enzyme weight and consequently the packaging and transportation costs will be decreased ${ }^{8}$. According to the relevant literature reviews several methods have been applied for the preparation of enzymes powder, including freeze drying ${ }^{9}$, spray drying ${ }^{10-12}$ and spouted bed drying ${ }^{13}$. Drying of the alpha-amylase in the presence of maltodextrin was studied in a spray dryer and the effects of effective operating parameters (the inlet/outlet air temperature and the feed flow rate) were investigated on the residual activity of the enzyme ${ }^{12}$. Drying of the alpha-amylase was also studied in freeze-drying through different freezing methods (utilization of freezer, liquid nitrogen, dry ice and acetone) and the obtained samples were compared with the dried powder prepared from the spray dryer. The results confirmed that the provided enzymes by both methods had significantly high activity ${ }^{9}$. Moreover Namaldi et al. ${ }^{11}$ investigate the effects of the inlet air temperature as well as type and concentration of glucose and maltodextrin on the activity of the serine alkaline protease in a spray dryer. According to their results presence of the additives had a significant effect on the enzyme activity during storage. Costa-Silva et al. ${ }^{14}$ studied the drying of the lipase in a spray dryer. In this report in order to evaluate the effect of additive on enzyme activity different ratios of lactose, maltodextrin, mannitol, gum arabic, trehalose, and $\beta$-cyclodextrin were added to the enzyme extract. The residual activity of the enzyme was determined after drying which was varied in the range of $63 \%$ to $100 \%$. Also, in another research, the lipase was immobilized on the agricultural waste and then dried through three methods including oven drying, spray drying, and freeze-drying. The obtained results demonstrated the higher 
activity of enzyme was obtained by spray drying method ${ }^{10}$. In a similar work Costa Silva et al. (2013) stabilized the lipase on the different agricultural wastes and fabricated samples were dried by the spouted bed reactor. According to their report this type of dryer could be a suitable technique for drying the heat-sensitive materials such as enzymes, foods and pharmaceuticals ${ }^{13}$. Among the mentioned dryer the spouted bed dryers can be used as a useful methodology, due to its advantages such as low cost ${ }^{15}$ and high volumetric evaporation rates under identical thermal conditions ${ }^{16}$. One of the oxidoreductase heat-sensitive enzymes is peroxidase that catalyzes a wide variety of reactions in the presence of peroxides. According to the literature, peroxidase has various applications in industries such as removal of the phenolic pollution from the wastewaters, decolorization of the synthetic paints, bio pulping and biobleaching, analysis and diagnostic kits, design, and construction of biosensors, and synthesis of aromatic amines and phenolic compounds and polymers ${ }^{17}$. Peroxidase can be extracted from the plants and animals or produced by microorganisms in the fermenter ${ }^{17,18}$. The enzyme extraction from the plant sources has considerable advantages including low production cost and renewability ${ }^{19}$. Up to now, peroxidase has been extracted from different plants such as Brassica rapa, Lycopersicon Esculentum, Raphanus Sativus L., Brassica oleracea ${ }^{20-23}$.

In this study, a spouted bed dryer was designed, constructed and applied for peroxidase enzyme drying for the first time. Peroxidase enzyme was extracted from garden radish (Raphanus sativus $L$.) as a low cost source of peroxidase ${ }^{24}$. Moreover, evaluating the influence of operating variables on the residual peroxidase activity is of great importance. The classical one-factor-at-a-time method is time-consuming and expensive. Moreover, this method is not capable of determining the interaction of interactions between different variables. In this study, full factorial experimental design was employed to evaluate the influence of input operating variables on residual peroxidase activity as the response. To achieve this goal, inlet air temperatures and flow rate selected as main factors. After process optimization, the drying performance on the catalytic activity of enzyme was evaluated by determination of an enzymatic reaction in the presence of the fresh enzyme extracts (FEE) and dried enzyme extracts (DEE). Kinetic parameters of the enzymatic reaction ( $V_{\max }$ and $K_{\mathrm{m}}$ ) were obtained using Michaelis-Menton (M-M) equation. Moreover, in order to evaluate the application of spouted bed dryer in enzyme drying the thermal stability and shelf-life of FEE and DEE were determined and compared. To the best of our knowledge, no experimental or modeling study has been investigated the peroxidase drying and its activity in a spouted bed dryer.

\section{Materials And Methods}

\subsection{Materials}

The roots of the garden radish were purchased from a local market. Also, hydrogen peroxide $\left(\mathrm{H}_{2} \mathrm{O}_{2}\right)$, 3,3',5,5'-tetramethylbenzidine (TMB), dipotassium phosphate $\left(\mathrm{K}_{2} \mathrm{HPO}_{4}\right)$, Monopotassium phosphate $\left(\mathrm{KH}_{2} \mathrm{PO}_{4}\right)$, bovine serum albumin (BSA), and Coomassie Brilliant Blue G-250 (CBBG) were all purchased from Sigma-Aldrich (St. Louis, MO, USA). Double distilled water used in all experiments. 


\subsection{Enzyme extraction and quantification}

The enzyme extract was obtained using the technique defined by Riazi et al. ${ }^{22}$ with a slight modification. The garden radish roots were peeled and the extract was prepared with a juicer. The slurry solution was then filtered, homogenized and stored in a freezer $\left(-20^{\circ} \mathrm{C}\right)$ until used. The total protein concentration of the extract was estimated according to Bradford's method ${ }^{25}$ using bovine serum albumin (BSA) as standard.

\subsection{Drying procedure}

The drying procedure was performed in a spouted bed consisted of a plexiglass cylindrical column with an inner diameter of $90 \mathrm{~mm}$ and a height of $300 \mathrm{~mm}$ that was connected to the conical base of the dryer (the internal angle of $60^{\circ}$ and the inlet orifice diameter of $15 \mathrm{~mm}$ ). The main components of the system were a heater with two elements by total power of $8 \mathrm{~kW}$, a blower with a power of $2.2 \mathrm{~kW}$ (GREENCO 2RB, China) which was equipped with a three-phase inverter, a peristaltic pump (WPX-1, Welco Co., Japan), an air flow meter, and a cyclone (Fig. 1). The temperature and humidity of the inlet and outlet air were controlled using the sensors installed at different points. Glass granules (diameter $3 \mathrm{~mm}$, sphericity 1 , density $2343.1 \pm 9.8 \mathrm{~kg} / \mathrm{m}^{3}$ ) were considered as the inert materials to be a carrier for the liquid film, a conductive heat transfer medium, and a mechanical cleaner of the bed ${ }^{26}$. In a typical test, after turning on the blower and heater, the flow rate and temperature of the inlet air were adjusted to the desired levels. When the outlet air temperature and humidity were in a steady state, a constant feed solution with $1.22 \pm$ $0.09 \mathrm{ml} / \mathrm{min}$ was dropped on the glass beads $(360 \mathrm{~g})$ using the peristaltic pump. The drying process was performed according to convective and conductive heat transfer in the bed. At the end of each experiment, the produced powder at the bottom of the cyclone was collected to analyze the enzyme activity. After each test, the granules were removed from the bed, washed several times and dried for further using.

\subsection{Minimum spouting airflow rate}

The minimum airflow rate to spout the inert glass beads was determined according to the method developed by Mathur and Epstein ${ }^{27}$ from the curve of the bed pressure drop versus the airflow rate. The bed pressure drop and airflow rate were measured using a digital differential manometer (Testo 510i) and a rotameter, respectively. Each experiment was repeated three times in order to provide acceptable level of reliability.

\subsection{Residual enzyme activity (REA)}

Peroxidase activity was determined according to the procedure described by Krainer et al. ${ }^{28}$. The reaction was started by the addition of $1 \mathrm{mM} \mathrm{H}_{2} \mathrm{O}_{2}$ to a solution including $0.6 \mathrm{mM} \mathrm{TMB}, 50 \mathrm{mM}$ potassium phosphate buffer, and the enzyme extract. The optical density was measured at $653 \mathrm{~nm}$ (extinction coefficient of oxidized TMB was $3.9 \times 104 \mathrm{~mol}^{-1} \mathrm{~cm}^{-1}$ ) by a spectrophotometer (Cary 50, Australia) for 180 seconds. The specific activity is defined as the ratio of the enzyme activity to the total protein amount ${ }^{29}$. 
REA was calculated as the ratio of the specific activity of the enzyme powder to the specific activity of the enzyme extract, as shown in Eq. (1) ${ }^{13}$ : see equation 1 in the supplementary files.

\subsection{Experimental design}

To evaluate the effect of drying conditions on the REA, the experimental design was conducted at different inlet air temperatures and flow rates. Minitab 17 software was used to design the experiment and analyze the obtained data. A full factorial design, considering the inlet air temperature at three levels of $50,60,70{ }^{\circ} \mathrm{C}$ and the dimensionless airflow rate at two levels of 1.2 and 1.4 resulted in 18 experiments that were performed with three times replication. To predict REA at different conditions, a first-order polynomial relationship relative to relevant variables has been presented in Eq. (2): see equation 2 in the supplementary files.

where, REA\% is the response of model, $\beta_{0}, \beta_{i}$, and $\beta_{i j}$ are the constant, linear, and interaction coefficients of the models, respectively. $X_{1}$ and $X_{2}$ are the inlet air temperature and dimensionless airflow rate (the ratio of the inlet airflow rate to the minimum spouting airflow rate), respectively ${ }^{30}$. To achieve the enzyme maximum residual activity, the obtained data were analyzed using RSM. Enzyme powder, obtained under the best drying conditions, was utilized in the subsequent experiments.

\subsection{The Catalytic activity of the enzyme}

To evaluate the activity of the dried peroxidase enzyme, the reaction of $0.6 \mathrm{mM}$ TMB with 1 mM hydrogen peroxide in the presence of the DEE and FEE was carried out ${ }^{28}$. The specific activity of the enzyme can be changed by the temperature, $\mathrm{pH}$, and concentration of the substrate. In order to find the optimum value of $\mathrm{pH}$, peroxidase activity was measured at various $\mathrm{pH}$ values from 3 to 10 at ambient temperature. The optimum temperature of the reaction was also determined by measurement of the FEE and DEE activity during the reaction at different temperature ranges $\left(10-85^{\circ} \mathrm{C}\right)$ under the optimum $\mathrm{pH}^{31}$.

\subsection{Kinetic parameters of the enzymatic reaction}

Under the obtained optimum conditions, the reaction between TMB and hydrogen peroxide was carried out in the presence of the peroxidase and different concentrations of the substrate (0.06-0.6 mM TMB) and the $1 \mathrm{mM} \mathrm{H}_{2} \mathrm{O}_{2}{ }^{31}$. The rate of the reaction at different conditions can be calculated by MichaelsMenten (M-M) equation. By inversing this equation, a linear relationship can be obtained which is called Line weaver-Burke Equation Eq. (3). The kinetic parameters of the reaction can be determined from the slope and intercept of this line ${ }^{32}$. See equation 3 in the supplementary files.

in this equation $V_{\mathrm{s}}$ is the reaction rate $(\mu \mathrm{M} / \mathrm{min} . \mathrm{mg}), V_{\mathrm{m}}$ is the Maximum reaction rate $(\mu \mathrm{M} / \mathrm{min} . \mathrm{mg})$ and $K_{\mathrm{m}}$ is the M-M equation constant (mM). The product of the mentioned reaction was a colored compound and the color changes with the reaction progress. Therefore, the intensity of light absorption could be determined at different times by a spectrophotometer. Finally, the concentration of the product $\left(C_{P}\right)$ at different times was determined from the Beer-Lambert equation. The plot of $C_{P}$ versus time, at different 
initial substrate concentrations, several slopes can be obtained. The reaction rate $\left(V_{s}, \mu M / m i n . m g\right)$ was calculated from dividing the slope of plots by the amount of the protein content.

\subsection{Peroxidase thermal-stability and self-life during storage}

To determine the possible variation in enzyme thermal-stability, the DEE and FEE were incubated for 10 min at different temperature ranges $\left(25-80^{\circ} \mathrm{C}\right)$ and then after $5 \mathrm{~min}$ incubation at room temperature, enzyme activity was measured ${ }^{2}$. The shelf-life of DEE and FEE during storage was followed by determination of the changes in the enzyme activity during storage at $-4{ }^{\circ} \mathrm{C}$.

\section{Results And Discussion}

\subsection{Minimum spouting airflow rate}

According to Fig. 2, the minimum spouting airflow rate (MS) was observed to be $355 \mathrm{l} / \mathrm{min}$. The ratio of airflow rate to $M S\left(Q_{i n}\right)$ in each experiment is a dimensionless parameter for investigating the effect of drying on the residual activity.

\subsection{Experimental design}

\subsubsection{Full factorial experiment design methodology and model consequence for REA}

The full factorial design matrix with two independent variables and consequences obtained from empirical experiments and model prediction are shown in Table 1. Based on the experimental data, the following equation Eq. (4) can be expressed as a model that shows a correlation between the REA and the operating variables: see equation 4 in the supplementary files.

To evaluate the importance and suitability of the obtained model, the analysis of variance (ANOVA) was carried out and the results are shown in Table 2. From table, it can be concluded that the regression model had a high determination coefficient $\left(R^{2}=0.95\right)$. 
Table 1. The results of full factorial design relevant to the residual enzyme activity.

$\begin{array}{llll}\text { Run } & \mathrm{T} & \mathrm{Q} & \begin{array}{l}\text { The residual } \\ \text { enzyme }\end{array} \\ \text { activity }(\%) & (\%)\end{array}$

\section{Experimental}

Predicted

1

50

$1.4 \quad 42.0$

39.1

7.4

32.0

16.1

25.0

32.0

38.2

27.1

25.0

27.1

38.2

25.0

16.1

16.1

32.0

38.2

39.1

39.1

27.1

\begin{tabular}{|lllll}
\hline 2 & 60 & 1.4 & 32.9 & 2.8 \\
\hline 3 & 70 & 1.2 & 17.9 & 11.2 \\
\hline 4 & 70 & 1.4 & 27.5 & 10.0 \\
\hline 5 & 60 & 1.4 & 33.5 & 4.7 \\
\hline 6 & 50 & 1.2 & 35.6 & 6.8 \\
\hline 7 & 60 & 1.2 & 30.2 & 11.4 \\
8 & 70 & 1.4 & 23.7 & 5.2
\end{tabular}




\begin{tabular}{|lllll}
\hline 9 & 60 & 1.2 & 27.3 & 0.7 \\
\hline 10 & 50 & 1.2 & 41.8 & 9.4 \\
\hline 11 & 70 & 1.4 & 22.5 & 10.0 \\
\hline 12 & 70 & 1.2 & 14.8 & 8.1 \\
\hline 13 & 70 & 1.2 & 14.4 & 10.6 \\
\hline 14 & 60 & 1.4 & 33.4 & 4.4 \\
\hline 15 & 50 & 1.2 & 35.6 & 6.8 \\
\hline 16 & 50 & 1.4 & 35.9 & 8.2 \\
\hline 17 & 50 & 1.4 & 35.3 & 9.7 \\
\hline
\end{tabular}

As can be observed all terms of the model (the linear and interaction terms) have a P-value less than 0.05 , which means both terms are significantly effective on REA. Moreover, the calculated F-value for the regression model is meaningfully higher than the acquired F-distribution which demonstrates the predicted strength of the fitted model. According to this result, the appropriate and credibility of the model are confirmed for the simulation of the REA.

Table 2. Analysis of variance relevant to the residual enzyme activity

\begin{tabular}{|lllll|}
\hline Source of variations & DF & Adjusted Mean Square & F-value & P-value \\
\hline Regression model & 3 & 378.726 & 86.79 & 0.000 \\
\hline Linear & 2 & 544.288 & 124.73 & 0.000 \\
\hline$T$ & 1 & 981.021 & 224.81 & 0.000 \\
\hline$Q$ & 1 & 107.556 & 24.65 & 0.000 \\
\hline$T^{*} \mathrm{Q}$ & 1 & 47.601 & 10.91 & 0.005 \\
\hline Error & 14 & 4.364 & - & - \\
\hline Lack-of-Fit & 2 & 1.844 & 0.39 & 0.688 \\
\hline Pure Error & 12 & 4.784 & - & - \\
\hline$R^{2}=94.90 \%, R^{2}$ adj $=93.80 \%, R^{2}$ pred $=90.59 \%$ & & & & \\
\hline
\end{tabular}

The residual analysis was used to further check the model adequacy. This analysis indicates the difference between the experimental data and the computed data by model. Fig. 3 illustrates the residual plots related to the residual data which was generated by 18 experimental runs. As can be seen the 
tendency in the all residual plots follow a normal distribution. Accordingly, it can be stated that the obtained model has a good adequacy and satisfactoriness.

Regression analysis of the experimental data include T-values, regression coefficients and P-values are shown in Table 3. The P-values were used as a tool to evaluate the significance and importance of each coefficients. The higher amount of the T-value and lower amount of the P-value, elucidate that the corresponding coefficient is more significant and has more effect on the response. The results demonstrated that the inlet air temperature $(p$-value $=0.0)$, flow rate $(p$-value $=0.0)$, and their interaction $(p$ value $=0.005)$ were significant parameters in peroxidase drying process. Moreover, as seen some of the coefficients are positive, as well as some of them are negative. The positive or negative coefficients display that these parameters will increase or decrease the response, respectively. Among discused parameters the $T$ had the negative effect on REA while $Q$ had positive effect.

Table 3. Estimated regression coefficients, T and P-values.

\begin{tabular}{|llll|}
\hline Terms & Coded coefficient & T-Value & P-Value \\
$\beta_{0}$ & 29.578 & 60.07 & 0.000 \\
$\beta_{1}$ & -9.042 & -14.99 & 0.000 \\
$\beta_{2}$ & 2.444 & 4.96 & 0.000 \\
$\beta_{1}{ }^{*} \beta_{2}$ & 1.992 & 3.30 & 0.005 \\
\hline
\end{tabular}

\subsubsection{Effect of the inlet air temperature and flow rate on the REA}

The effect of the inlet air temperature and the flow rate on the REA has been illustrated in Fig. 4. As it is obvious from Fig. 4a, the flow rate has the positive effect and REA increases with the increment of the flow rate and at the constant values of $\mathrm{T}$. Conversely, the inlet air temperature has negative effect on REA and an increase in the inlet air temperature from 50 to $70^{\circ} \mathrm{C}$ lead to decrease in the REA. The results depicted in Fig. 4a demonstrated that at higher inlet air temperatures, the positive effect of the inlet air flow rate was more noticeable on REA, compared to lower temperatures. Furthermore, the slope rate of lines in Fig. $4 \mathrm{~b}$ is different, which indicates the importance of effect of each factor on the REA.

In order to further investigate the influence of each factor on REA and also to discover the relative optimum range, the contour and surface plots was obtained. Fig. 4c-4d depict the contour and response surface plots as a function of two input operating factors whereas the other input parameters are held constant at their mean amounts. The darker area in Fig. 4c indicates the higher amount of REA. Fig. 4d represents the effect of the temperature and the air flow rate on REA; it can be seen that the maximum of these parameters occurred at $\mathrm{T}=50^{\circ} \mathrm{C}$ and $\mathrm{Q}=1.4$. 
According to the obtained results, it was found that by increasing the temperature, the REA decreased. This outcome is in agreement with the related researches in the literature ${ }^{11,12}$. Indeed, increasing the temperature can change the chemical structure of the enzyme and therefore reduce the enzyme activity. On the other hand, at the higher inlet airflow rate, due to the lower residence time of the powder, the enzyme was less affected by the heat and then the amount of the REA was increased. Under the best drying conditions $\left(T=50^{\circ} \mathrm{C}\right.$ and $\left.\mathrm{Q}=1.4\right)$, the REA was obtained to be about $37.7 \%$.

\subsection{Effect of drying on the catalytic activity of the enzyme}

The effect of $\mathrm{pH}$ on the enzymatic reaction at $25^{\circ} \mathrm{C}$ has been shown in Fig. $5 \mathrm{a}$. By increasing the pH value from 3 to about 5.75 and 5 for FEE and DEE, respectively, the specific activity of enzyme was enhanced. Further increase in $\mathrm{pH}$ value reduced the residual enzyme activity. As the result it was inferred that the optimum values of 5.75 can be considered for FEE and in the same way optimum pH value of 5 can be considered for DEE. The effect of temperature on the enzymatic reaction at the obtained optimum $\mathrm{pH}$ has been shown in Fig. $5 \mathrm{~b}$. The optimum temperature of the reaction, catalyzed by FEE and DEE was observed at about $35^{\circ} \mathrm{C}$ and $65^{\circ} \mathrm{C}$, respectively. As can be seen in this figure, although the activity reduction owing to drying is noticeable, the optimum temperature of the enzymatic reaction has been increased in the presence of peroxidase as powder form.

As shown in Fig. 5 the physicochemical properties of the enzyme have been affected upon drying. The optimum $\mathrm{pH}$ shifted to the acidic $\mathrm{pH}$ in DEE compared with the FEE. Interestingly, the optimum temperature of the reaction for DEE is increased by more than 1.8 fold.

\subsection{Effect of drying on the kinetics of the peroxidase reaction}

In order to evaluate the influence of initial concentrations of TMB on the product concentration, the experiments were carried out in the presence of different concentration of FEE and DEE (0.06-0.6 mM) and the obtained results are presented in Fig. $6 a$ and b. As can be seen, at earlier times of reaction (about until 3 minutes), the slope of each line is constant and independent of the substrate concentration.

Therefore, for each line, an initial rate was obtained in accordance with the initial substrate concentration. The reaction rates were obtained by dividing the obtained slope by the amount of the protein content. The obtained results from Fig. 6 , the initial slopes and the reaction rates, are reported presented in Table 4 for dried enzyme and the fresh extracted one. 


\begin{tabular}{|c|c|c|c|c|}
\hline $\begin{array}{l}\mathrm{C}_{0, \mathrm{TMB}} \\
(\mathrm{mM})\end{array}$ & $\begin{array}{l}\text { Slope }_{\text {DEE }} \\
(\mu \mathrm{M} / \mathrm{min})\end{array}$ & Slope $_{\mathrm{FEE}}(\mu \mathrm{M} / \mathrm{min})$ & $\begin{array}{l}\text { Reaction rate }\left(V_{s_{D E E}}\right) \\
(\mu \mathrm{M} / \text { min.mg })\end{array}$ & $\begin{array}{l}\text { Reaction rate }\left(V s_{\mathrm{FEE}}\right) \\
(\mu \mathrm{M} / \mathrm{min} \cdot \mathrm{mg})\end{array}$ \\
\hline 0.06 & $1.44 \pm 0.07$ & $0.30 \pm 0.00$ & $9234 \pm 419$ & $22087 \pm 109$ \\
\hline 0.09 & $2.11 \pm 0.19$ & $0.42 \pm 0.02$ & $13508 \pm 1197$ & $30439 \pm 1135$ \\
\hline 0.12 & $2.62 \pm 0.21$ & $0.46 \pm 0.03$ & $16754 \pm 1338$ & $33626 \pm 2051$ \\
\hline 0.15 & $3.24 \pm 0.03$ & $0.55 \pm 0.051$ & $20723 \pm 172$ & $40000 \pm 3736$ \\
\hline 0.18 & $3.69 \pm 0.20$ & $0.68 \pm 0.01$ & $23613 \pm 1290$ & $49487 \pm 842$ \\
\hline 0.2 & $4.36 \pm 0.29$ & $0.69 \pm 0.02$ & $27938 \pm 1837$ & $50329 \pm 1684$ \\
\hline 0.4 & $5.94 \pm 0.19$ & $0.93 \pm 0.00$ & $38018 \pm 1245$ & $68095 \pm 256$ \\
\hline 0.6 & $6.78 \pm 0.23$ & $0.97 \pm 0.04$ & $43418 \pm 1446$ & $70842 \pm 2637$ \\
\hline
\end{tabular}

According to Eq. (6) by drawing the inverse of the reaction rates versus the initial substrate concentrations the M-M parameters ( $K_{\mathrm{m}}$ and $V_{\mathrm{m}}$ constants) were obtained (Fig. 7a) which are presented in Table 5. After obtaining the constants, the rate of the reaction could be calculated from the M-M equation for different concentrations. The calculated rates from the M-M equation and the experimental data are presented in Fig. 7b. As can be seen a clear decrease in enzyme activity observed in DEE. The calculations showed that the FEE activity was reduced by $48.9 \%$, on average, after the drying process.

In addition to the physicochemical properties, the kinetic parameters of peroxidase were also affected upon enzyme drying, which may be due to peroxidase structural changes. Based on the results, as a consequence of drying, the affinity of the enzyme to substrate increased and the maximum reaction rate $\left(V_{\mathrm{m}, \mathrm{DEE}}\right)$ decreased. Indeed, amino hydrophilic acids are in the exterior structure of the enzyme, creating hydrogen bonds between the enzyme and the water molecules ${ }^{33}$. As a result of drying, the aqueous medium around the enzyme is removed, causing hydrogen bonds to break down ${ }^{34}$, which leads to an increase in the salt concentration followed by a change in the electrostatic interaction between charged amino acids ${ }^{35}$. These changes may cause a variation in the enzyme. Changes in kinetic properties as a result of enzyme structure variation during drying has been reported previously ${ }^{2-6}$. 
Table 5. The obtained kinetic parameters of the dried extracted enzyme (DEE) and freshly extracted enzyme (FEE)
$\mathrm{V}_{\mathrm{m}, \mathrm{FEE}}$
$\mathrm{V}_{\mathrm{m}, \mathrm{DEE}}$
$\mathrm{K}_{\mathrm{m} \text {, FEE }}$
$\mathrm{K}_{\mathrm{m}, \mathrm{DEE}}$
( $\mu \mathrm{M} /$ min.mg)
( $\mu \mathrm{M} / \mathrm{min} \cdot \mathrm{mg})$
$(\mathrm{mM})$
$(\mathrm{mM})$
100583.38
93370.68
0.21
0.54

\subsection{Effect of drying on the thermal-stability and shelf-life during storage}

Relative activity at each temperature indicates the ratio of the specific peroxidase activity at a specific temperature to the maximum specific peroxidase activity which is the specific peroxidase activity at $45^{\circ} \mathrm{C}$ 36. As can be seen in Fig. 8, the enzyme powder showed more stability toward heating compared to the extract one. For instance, at $80{ }^{\circ} \mathrm{C}$, enzyme extract activity tended to be zero, while more than $30 \%$ of the enzyme powder activity remained. Moreover, the shelf-life of the powder and extract was examined during storage. The peroxidase powder maintained $87.24 \%$ of its initial activity after storage at $-4{ }^{\circ} \mathrm{C}$ for 9 months while the peroxidase extract lost about $20 \%$ of its initial activity after one-month storage at the same temperature.

In accordance with Fig. 8, the thermal stability of the enzyme powder was improved during drying in the spouted bed dryer. Although the increase of enzyme thermal-stability was reported by several methods

2,35 but to the best of our knowledge, this is for the first time that the enhancement of peroxidase thermalstability was reported by drying process. Shelf-life of the DEE during storage was also improved owing to drying in the spouted bed reactor, which is in agreement with the results of the enzyme drying in spray dryer ${ }^{37}$. Generally, improvement of optimum temperature, thermal stability, and shelf-life during storage has several advantages for the utilization of dried enzymes in industries which result in low-cost storage and long-time preservation as well as its use at higher temperatures ${ }^{1,8}$.

\section{Conclusion}

The enzymes can be extracted directly from the natural resources of plants and animals; however, due to short shelf-life of fresh enzymes these materials should be dried. In this research study the root ingredients of garden radish, which is a rich source of the peroxidase, were extracted and the resulting paste was dried using the spouted bed dryer with inert glass beads. The effect of important operating factors (the inlet air temperature and the air flow rate) and their interaction on the residual activity of enzyme were established by full factorial experimental design methodology for the first time. The ANOVA and Pareto analysis indicated that the inlet air temperature, contrary to the air flow rate, had a negative effect on residual activity of enzyme. After evaluating the optimum values of operating factors $\left(T=50^{\circ} \mathrm{C}\right.$ and $Q=1.4)$, the effect of drying process on the thermal-stability and enzyme activity of enzyme was 
investigated. The obtained results indicated a reduction of the enzyme activity after drying process which can be due to a change in peroxidase structure. The kinetic studies were done according to the MichaelisMenton (M-M) equation and $V_{\max }$ and $K_{\mathrm{m}}$ of enzymatic reaction were obtained for different TMB concentrations. According to the stability studies it was confirmed that spouted bed drying of peroxidase enzyme had impressive effect on thermal-stability and shelf-life which improved up to $50 \%$ compare to fresh enzyme. Overall, it could be concluded that the spouted bed dryer can be a promising method to be considered as a successful unit operation for drying the heat-sensitive materials such as enzymes.

\section{Declarations}

\section{Acknowledgement}

The authors are thankful to the University of Shahid Bahonar, Kerman for the technical support of the project.

\section{Conflicts of interest/Competing interests}

The authors declare that they have no conflict of interest.

\section{References}

1 Pilosof, A. M. R. \& Sanchez, V. E. in Handbook of Industrial Drying (ed A. S. Mujumdar) 981-990 (Taylor \& Francis, 2006).

2 Sarvandi-Dehghanpoor, E., Riahi-Madvar, A., Lotfi, S. \& Torkzadeh-Mahani, M. Improvement of kinetic properties and thermostability of recombinant Lepidium draba peroxidase (LDP) upon exposed to osmolytes. International journal of biological macromolecules119, 1036-1041 (2018).

3 Riahi-Madvar, A. \& Hosseinkhani, S. Design and characterization of novel trypsin-resistant firefly luciferases by site-directed mutagenesis. Protein Engineering, Design \& Selection22, 655-663 (2009).

4 Homaei, A. A., Sariri, R., Vianello, F. \& Stevanato, R. Enzyme immobilization: an update. Journal of chemical biology6, 185-205 (2013).

5 Zhou, X., Li, H. \& Zheng, L. Directly covalent immobilization of Candida antarctica lipase B on oxidized aspen powder by introducing poly-lysines: An economical approach to improve enzyme performance. International journal of biological macromolecules133, 226-234 (2019).

6 Zdarta, J., Meyer, A. S., Jesionowski, T. \& Pinelo, M. A general overview of support materials for enzyme immobilization: characteristics, properties, practical utility. Catalysts8, 92 (2018).

$7 \quad$ Maltesen, M. J. \& Van De Weert, M. Drying methods for protein pharmaceuticals. Drug Discovery Today: Technologies5, e81-e88 (2008). 
8 Araya-Farias, M. \& Ratti, C. in Dehydration of Foods: General Concepts (ed C. Ratti) 20-55 (Taylor \& Francis, 2009).

9 De Jesus, S. \& Maciel Filho, R. Drying of a-amylase by spray drying and freeze-drying-a comparative study. Brazilian Journal of Chemical Engineering31, 625-631 (2014).

10 Costa-Silva, T., Souza, C., Said, S. \& Oliveira, W. Drying of enzyme immobilized on eco-friendly supports. African Journal of Biotechnology14, 3019-3026 (2015).

11 Namaldi, A., Çalik, P. \& Uludag, Y. Effects of spray drying temperature and additives on the stability of serine alkaline protease powders. Drying Technology24, 1495-1500 (2006).

12 Samborska, K., Witrowa-Rajchert, D. \& Gonçalves, A. Spray-drying of a-amylase-The effect of process variables on the enzyme inactivation. Drying Technology23, 941-953 (2005).

13 Costa-Silva, T., Cognette, R., Souza, C., Said, S. \& Oliveira, W. P. d. Spouted bed drying as a method for enzyme immobilization. Drying technology31, 1756-1763 (2013).

14 Costa-Silva, T. A., Nogueira, M. A., Fernandes Souza, C. R., Oliveira, W. P. \& Said, S. Lipase production by endophytic fungus Cercospora kikuchii: stability of enzymatic activity after spray drying in the presence of carbohydrates. Drying Technology29, 1112-1119 (2011).

15 Dotto, G. L., Souza, V. C. \& Pinto, L. A. Drying of chitosan in a spouted bed: The influences of temperature and equipment geometry in powder quality. LWT-Food Science and Technology44, 1786-1792 (2011).

16 Kudra, T. \& Mujumdar, A. S. Special drying techniques and novel dryers. (2006).

17 Hamid, M. Potential applications of peroxidases. Food chemistry115, 1177-1186 (2009).

18 Azevedo, A. M. et al. Horseradish peroxidase: a valuable tool in biotechnology. Biotechnology annual review9, 1387-2656 (2003).

19 Hatti-Kaul, R. in BIOTECHNOLOGY (eds H. Doelle, S. Roken, \& M. Berovic) (2009).

20 Kokkinakis, D. M. \& Brooks, J. L. Tomato peroxidase: purification, characterization, and catalytic properties. Plant Physiology63, 93-99 (1979).

21 Motamed, S., Ghaemmaghami, F. \& Alemzadeh, I. Turnip (Brassica rapa) peroxidase: purification and characterization. Industrial \& engineering chemistry research48, 10614-10618 (2009).

22 Riazi, Z., Ziai, S., Shariat, S., Farshchi, P. \& Khalili, F. Optimization of Garden radish (Raphanus Sativus L.) Peroxidase Enzyme for Removal of 2, 4-dichlorophenol from 2, 4-Dichlorophenoxyacetic Acid Wastewater. (2012). 
23 ZAHIDI, T. et al. Extraction and comparison of two new peroxidases from leaves and roots of Brassica oleraceae var. ramosa. (2018).

24 Fricks, A. T. et al. Evaluation of radish (Raphanus sativus L.) peroxidase activity after highpressure treatment with carbon dioxide. The Journal of supercritical fluids38, 347-353 (2006).

25 Bradford, M. M. A rapid and sensitive method for the quantitation of microgram quantities of protein utilizing the principle of protein-dye binding. Analytical biochemistry72, 248-254 (1976).

26 Adamiec, J., W., K. s., Markowski, A. S. \& Strumiłło, C. in Handbook of industrial drying (ed A. S. Mujumdar) 924-948 (Taylor \& Francis, 2006).

27 Mathur, K. B. \& Epstein, N. Spouted Beds. (1974).

28 Krainer, F. W. et al. Purification and basic biochemical characterization of 19 recombinant plant peroxidase isoenzymes produced in Pichia pastoris. Protein expression and purification95, 104-112 (2014).

29 Bezerra, R. P. et al. Extraction of amylase from fermentation broth in poly (ethylene glycol) salt aqueous two-phase system. Brazilian Archives of Biology and Technology49, 547-555 (2006).

30 Montgomery, D. C. Design and analysis of experiments. (2017).

31 Fattahian, Y., Riahi-Madvar, A., Mirzaee, R., Torkzadeh-Mahani, M. \& Asadikaram, G. Heterologous expression, purification and characterization of a peroxidase isolated from Lepidium draba. The protein journa/36, 461-471 (2017).

32 Shuler, M. L. \& Kargi, F. Bioprocess Engineering Basic Concepts. (Prentice Hall Inc, 2002).

33 Lodish, H. et al.Molecular cell biology. (Macmillan, 2008).

34 Millqvist-Fureby, A., Malmsten, M. \& Bergenståhl, B. Spray-drying of trypsin-surface characterisation and activity preservation. International journal of pharmaceutics188, 243-253 (1999).

35 Wang, W. Lyophilization and development of solid protein pharmaceuticals. International journal of pharmaceutics203, 1-60 (2000).

36 Chao, C. et al. Surface modification of halloysite nanotubes with dopamine for enzyme immobilization. ACS applied materials \& interfaces5, 10559-10564 (2013).

37 Ajmera, A. \& Scherließ, R. Stabilisation of proteins via mixtures of amino acids during spray drying. International Journal of Pharmaceutics463, 98-107 (2014).

\section{Figures}




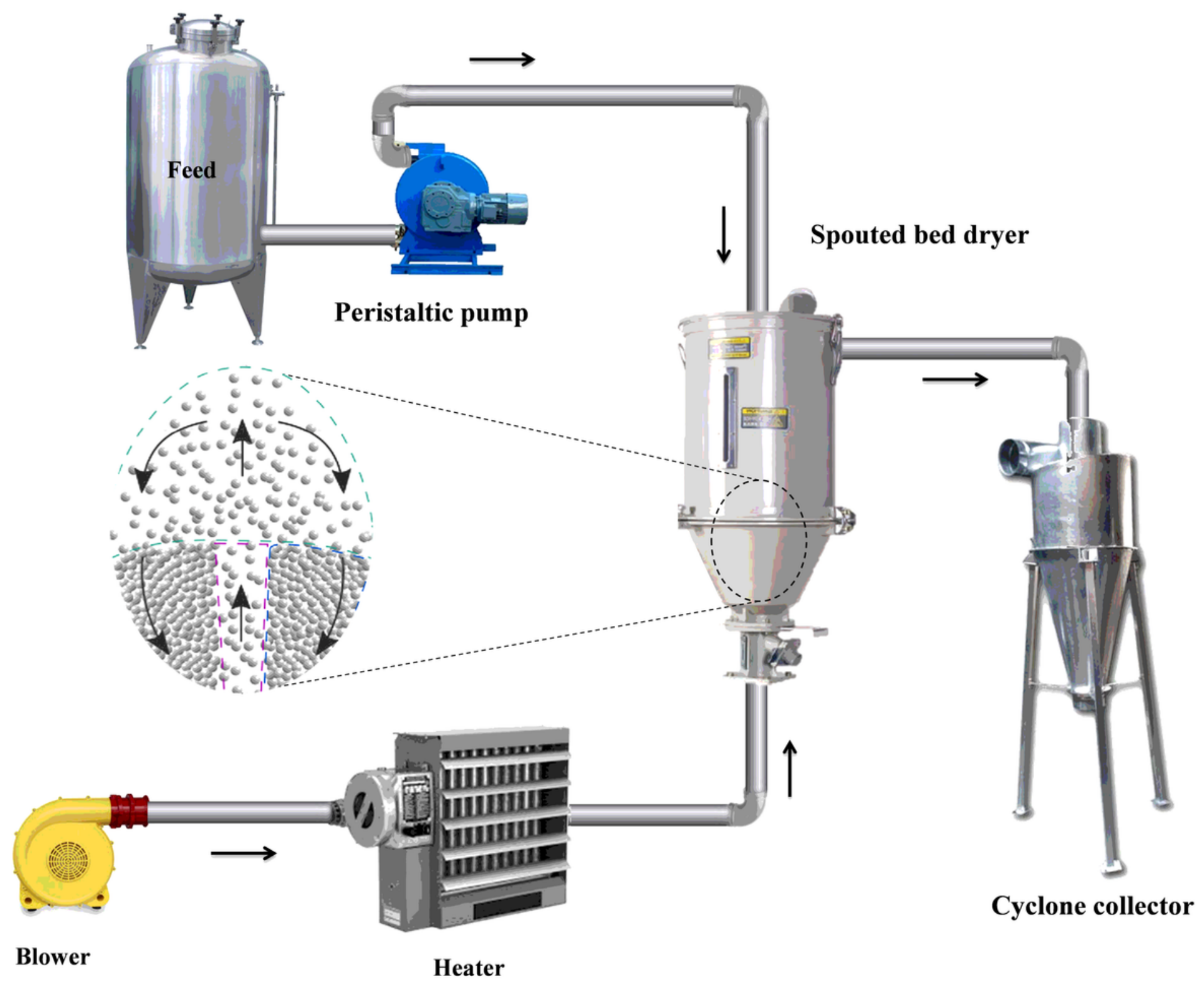

Figure 1

Schematic diagram of the spouted bed dryer. 


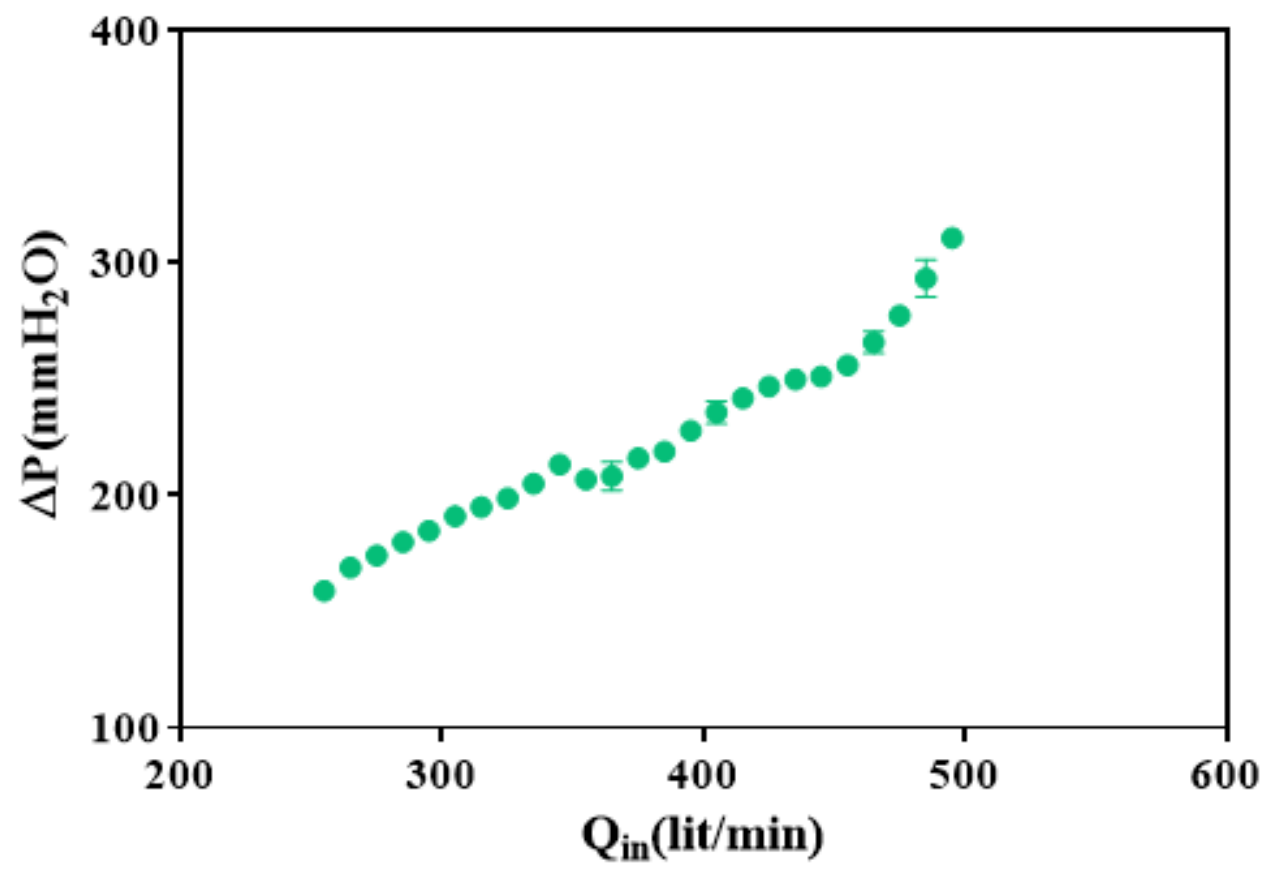

Figure 2

Pressure drop $(\Delta P)$ versus the ratio of airflow rate to MS (Qin)
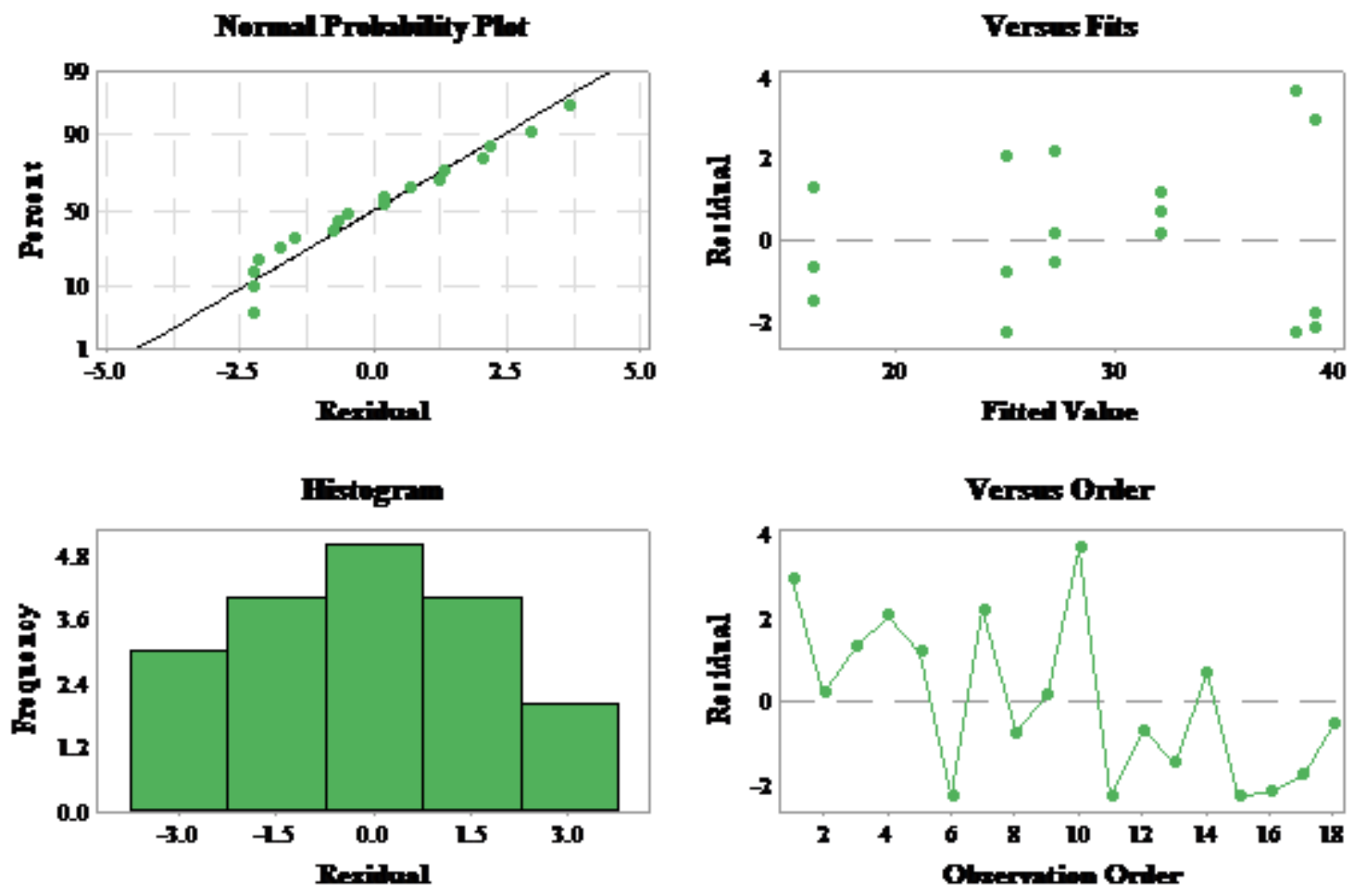

Figure 3

Residual plots for residual peroxidase activity 


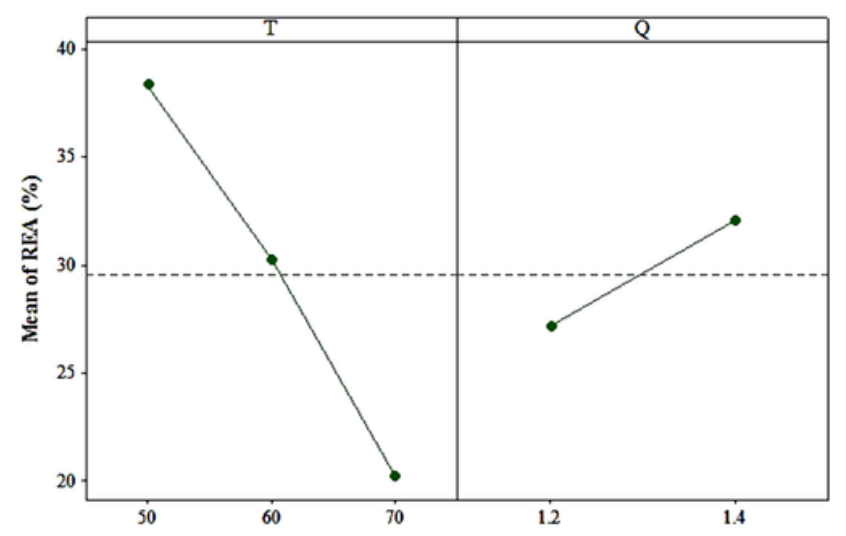

(a)

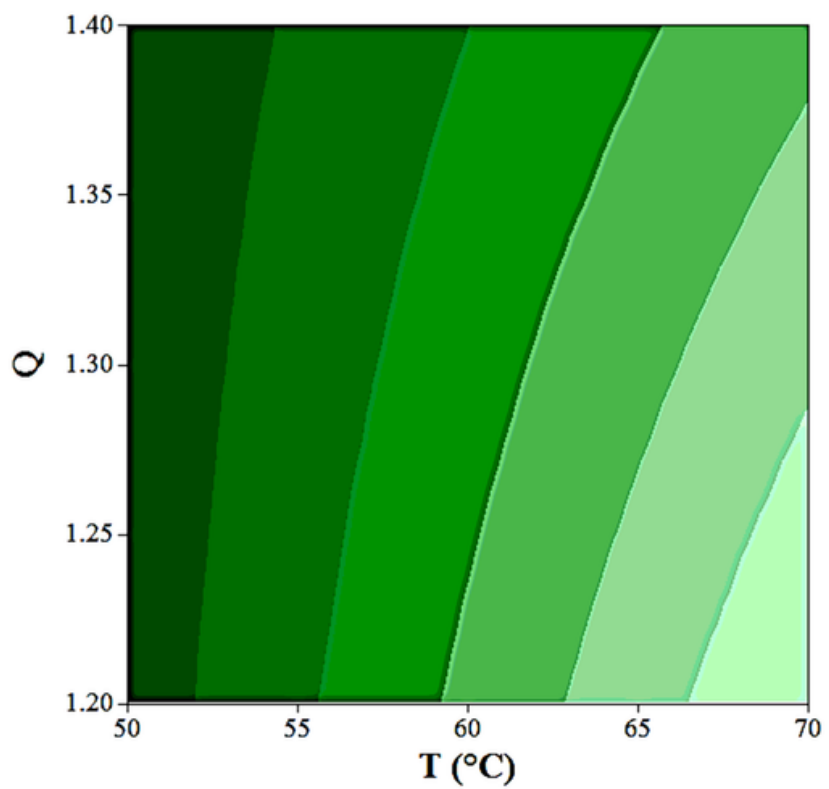

(c)

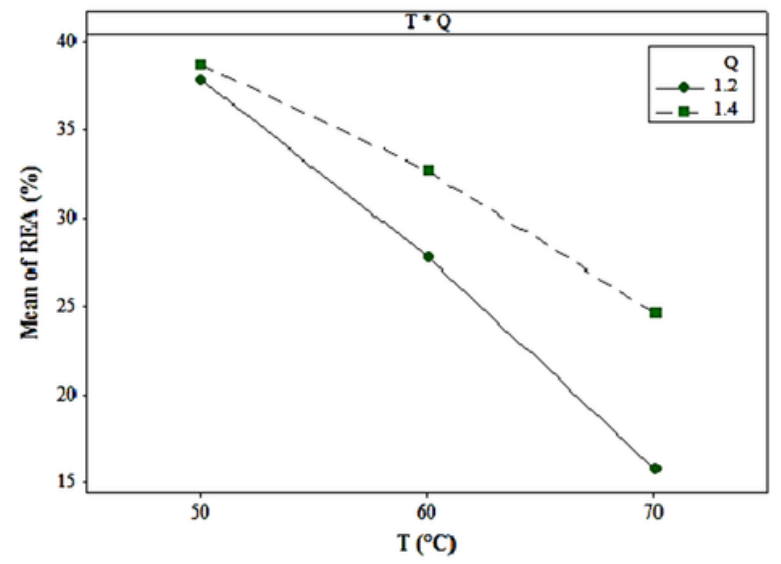

(b)

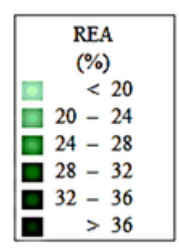

(\%)

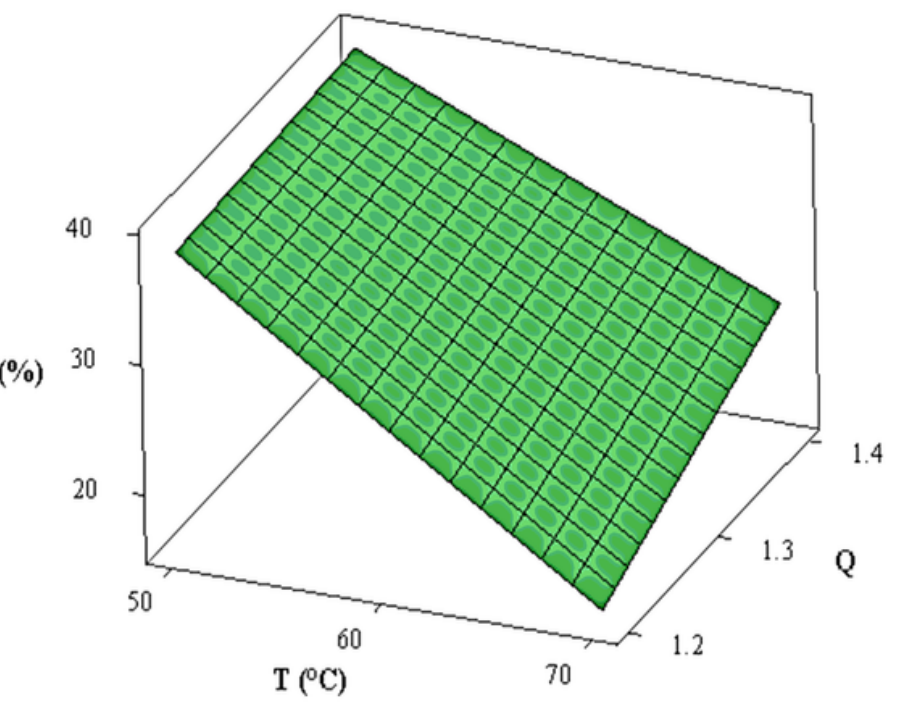

(d)

\section{Figure 4}

(a) The effect of the inlet air temperature $(T)$ and flow rate ( $Q$ ) on the residual enzyme activity (REA), (b) the interaction effect of $T$ and $Q$ on the REA, (c) the contour and (d) response surface plot of the REA (\%) 

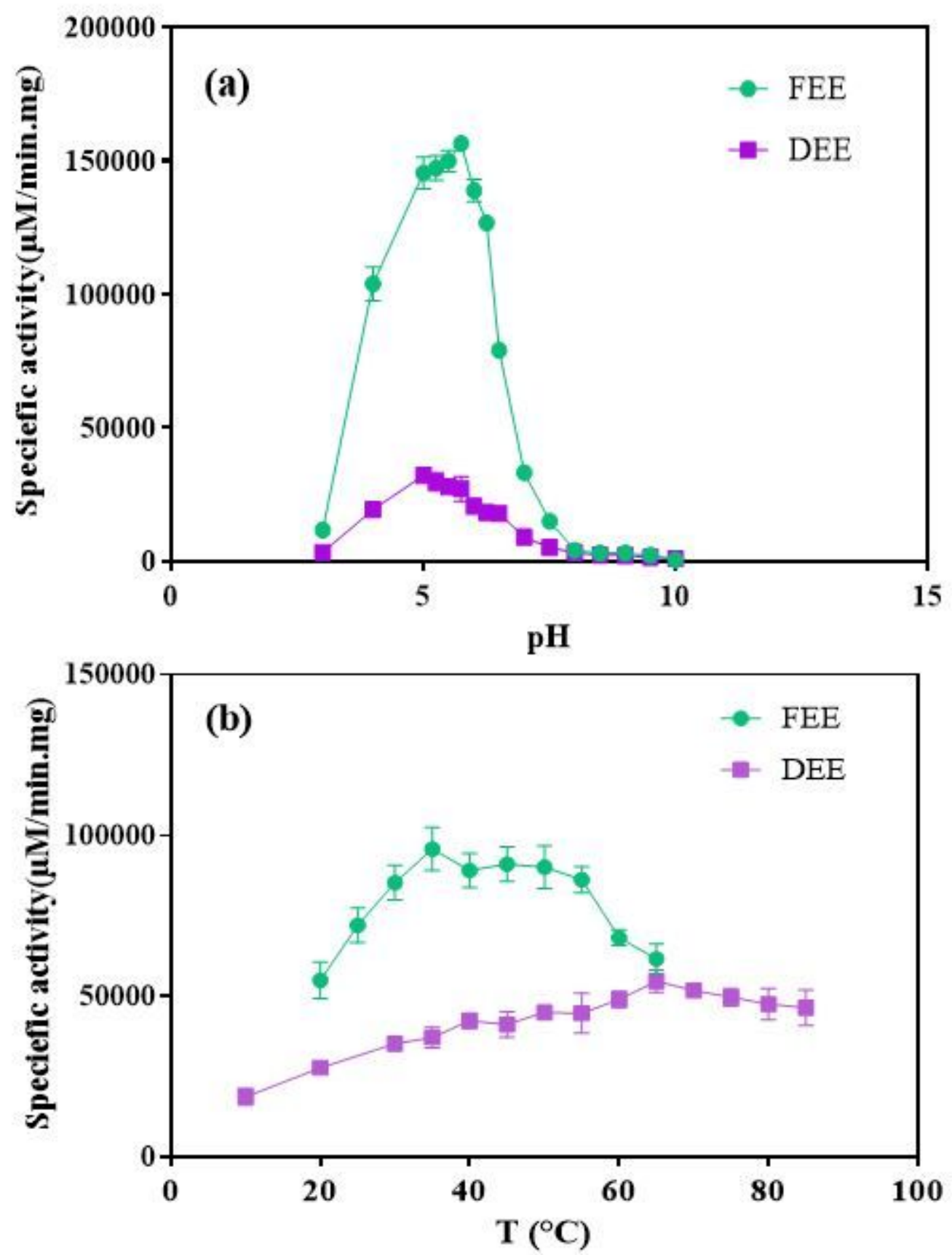

Figure 5

The optimum conditions of the enzymatic reaction in the presence of the freshly extracted enzyme (FEE) and the dried extracted enzyme (DEE) (a) experiment at the ambient temperature and different $\mathrm{pH}$ ranges (3-10) (b) at the optimum $\mathrm{pH}$ and different temperature ranges $\left(10-85^{\circ} \mathrm{C}\right)$ 

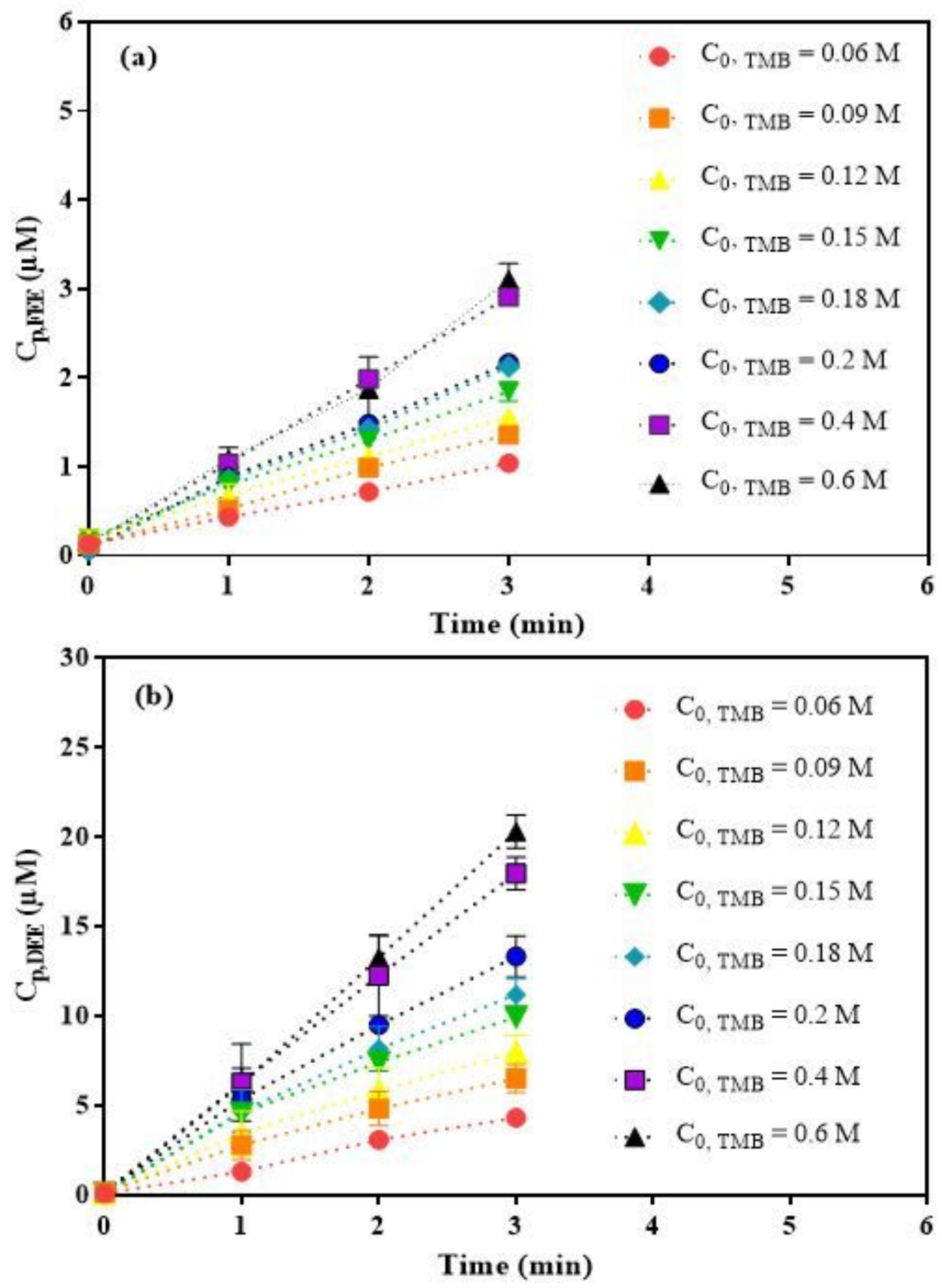

Figure 6

The concentration of the colored product versus time at different initial concentrations of the substrate (a) for the freshly extracted enzyme (FEE), and (b) for the dried extracted enzyme (DEE) 

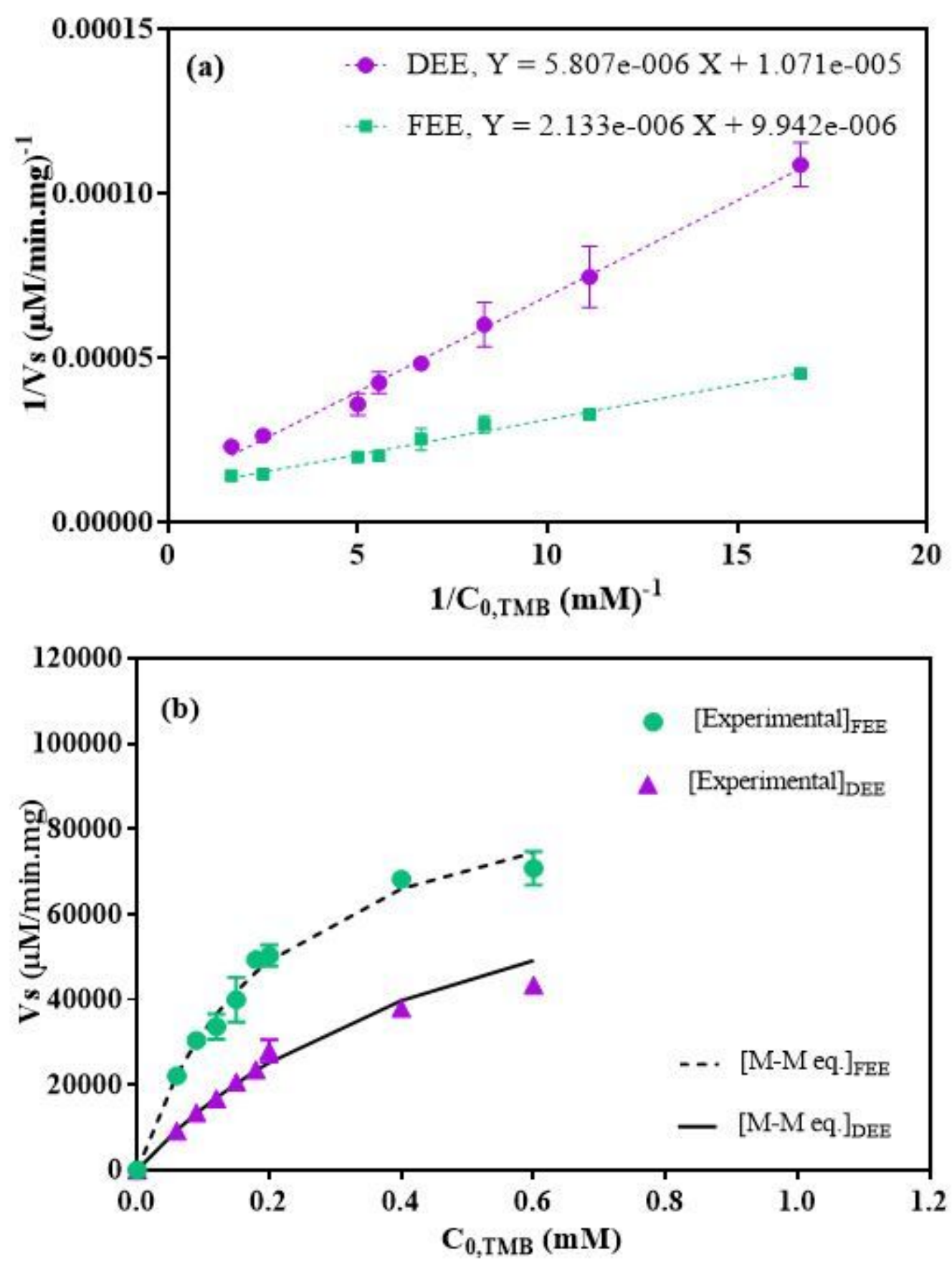

Figure 7

(a) Lineweaver-Burke Equation parameters "equation (6)" (b) The initial reaction rate obtained from the M$M$ equation and also, the experimental data at different substrate concentrations using the dried extracted enzyme (DEE) and freshly extracted enzyme (FEE) 


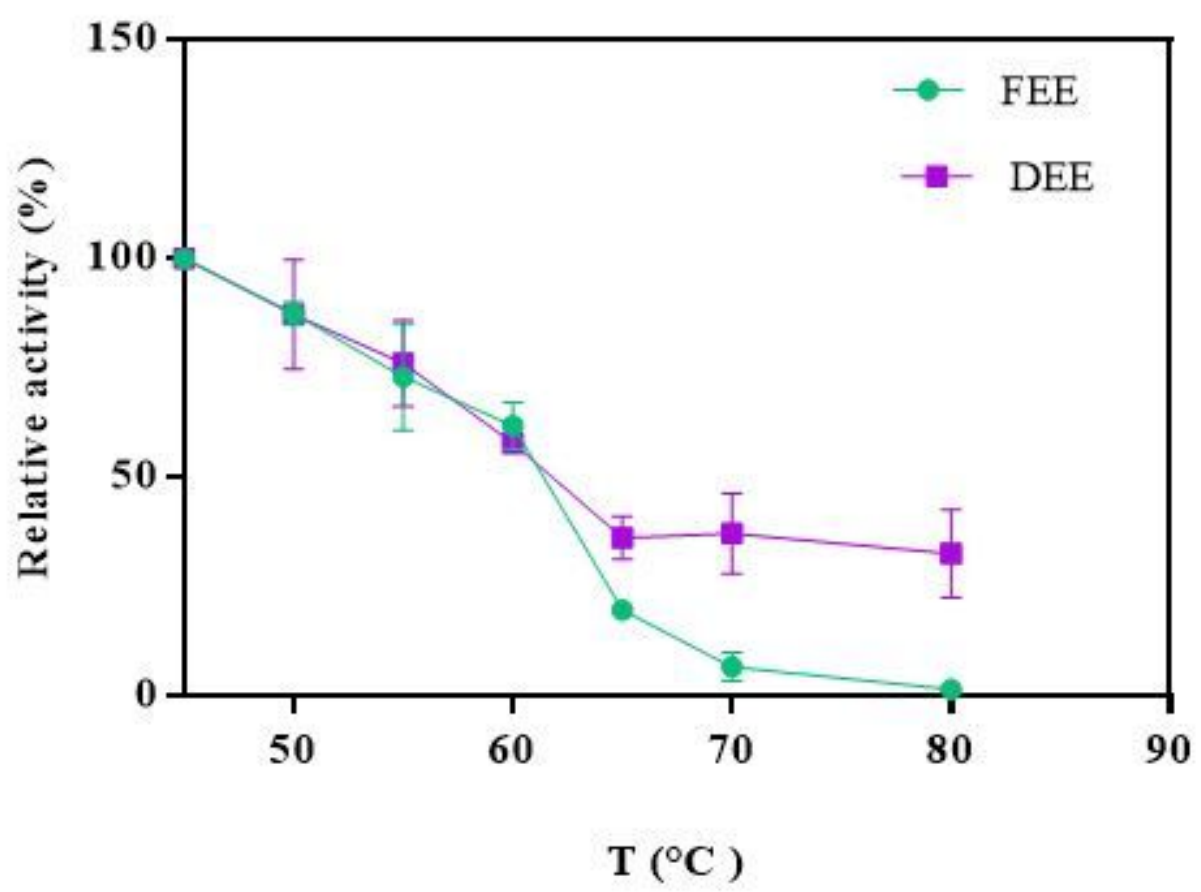

Figure 8

Thermal-stability of the peroxidase as the dried extracted enzyme (DEE) and freshly extracted enzyme (FEE) 